\title{
Financial and Credit Mechanism for Attraction of Real Investments in a System of Money Flows Regulation
}

\author{
Larisa Ivanovna Yuzvovich \\ Department of Insurance Ural Federal University named after the first President of Russia B.N. Yeltsin, Russia, \\ Ekaterinburg, 620002, Ekaterinburg, 19 Mira, Str. \\ Elena Gennadevna Knyazeva \\ Department of Insurance Ural Federal University named after the first President of Russia B.N. Yeltsin, Russia, \\ Ekaterinburg, 620002, Ekaterinburg, 19 Mira, Str. \\ Roman Yurevich Lugovtsov \\ Department of Insurance Ural Federal University named after the first President of Russia B.N. Yeltsin, Russia, \\ Ekaterinburg, 620002, Ekaterinburg, 19 Mira, Str. \\ Elena Vladimirovna Kuklina \\ Department of Insurance Ural Federal University named after the first President of Russia B.N. Yeltsin, Russia, \\ Ekaterinburg, 620002, Ekaterinburg, 19 Mira, Str.

\section{Valeriya Borisovna Rodicheva} \\ Department of Insurance Ural Federal University named after the first President of Russia B.N. Yeltsin, Russia, \\ Ekaterinburg, 620002, Ekaterinburg, 19 Mira, Str.
}

\section{Doi:10.5901/mjss.2015.v6n3s3p95}

\section{Abstract}

Optimization of funding sources of real investments is a key stage in development and successful functioning of enterprises' investment activity. Currently big attention is drawn to questions of state and private partnership during development of investment projects, as well as to possible prospects of development of state and private interaction forms in investment sphere, and concessions particularly. Improvement of forms of interaction between state and corporate sector of economy in the sphere of real investments and as a part of development of specific priority investment programs requiring considerable investments has a strategic federal and regional value. Thus, it is important to understand role and benefit of each participant of the investment market, to define clear statutory, legislative and contractual base, and to swiftly analyze financial efficiency of real investments at all stages of realization. In modern conditions, stable development of economy of any country depends on condition of investment process. Need to integrate finance capital and to promote investment activity is obvious in new management conditions of market relations development. The main condition of successful investment activity at each stage is a choice of effective and correct finance and credit mechanism as a tool of real investments financing. Prior to suggest modern tools of such financing, it is necessary to analyze theoretically proved program and targeted method of real investments financing within the state and private partnership, in order to improve previously examined methodology.

Keywords: financial and credit mechanism, financing of investment, program and targeted method, investment policy of a state.

\section{Introduction}

\subsection{Introduce the Problem}

A conceptual approach to studying and examination of program and targeted method of real investments financing presupposes definition of its essence, target milestones, problems, advantages and purpose.

The scientific article contains developed methodological aspects of the financial and credit mechanism for 
attraction of real investments in money flows regulation system, on the basis of program and targeted method of formation of enterprise's investment resources.

In modern conditions, stable development of economy of any country depends on condition of investment process. Need to integrate finance capital and to promote investment activity is obvious in new management conditions of market relations. The main condition of successful investment activity at each stage is a choice of effective and correct finance and credit mechanism.

\subsection{Importance of the Problem}

Theoretical importance of scientific research consists in a fact that its results broaden theoretical and methodological base for development of more effective financial and credit mechanism for attraction of real investments.

Reasonable assumptions of the author served as a basis of scientific and practical solutions for arrangement of investment process at several business entities, assessment of their financial condition in order to estimate prospects of investment activity realization. The key points of research are used in practical activities of business entities of Sverdlovsk oblast. The key points of research are used in practical activities of financial and industrial groups Ural Federal district, enterprises of pipe and tube production.

\subsection{Relevant Scholarship}

The main conclusions and recommendations of thesis work were reported, discussed and have been approved at XIII International theoretical and practical conference «Unexpected present: changing realities of the XXI century. World Russia - Ural» (Ekaterinburg - 2010); at VII International theoretical and practical conference «Stable development of the Russian regions: innovations, institutes and technological loans» (Ekaterinburg, - 2010); at III All-Russia theoretical and practical conference «Trends of development of the Russian regions: problems and solutions» carried out by department of science and education of the Tyumen oblast, «Tyumen state academy of economic, management and law» («TGAMEUP») on February, 9th, 2011; International scientific conference «Economic mechanism of innovative development». Australia, March, 26th - April, 6th, 2011; at VIII International theoretical and practical conference on problems of economic development in the modern world "Stable development of the Russian regions: man and modernisation" (Ekaterinburg, April, 22-23nd, 2011).

\subsection{State Hypotheses and Their Correspondence to Research Design}

Modern paradigm, concept of functioning of the financial and credit mechanism in interaction with current investment policy in a system of money flows regulation was described; methodological approaches to the system of formation of investment resources at the enterprise were examined; economic content of program and targeted method of real investments financing as a part of state and private partnership was defined.

\section{Method}

\subsection{Method of statistical monitoring}

The information base is quite representative which creates a reliable basis for creation of coherent view of a complex technique for investment projects analysis on the basis of analytical materials of theoretical and practical conferences; expert data from periodicals; reference materials and electronic information systems.

\subsection{Method of analysis and measurement}

The author suggests using a program and targeted investment method in state financing of real investments in order to promote state and private partnership in the investment business.

The essence of program and targeted method of real investments financing consists in selection of the main objectives of investment development, arrangement of actions for their achievement within the planned terms at balanced support with financial resources taking into account their effective application. The basis of program and targeted method is a system of programs which are implemented by state bodies of different level, or by private companies with state support. 
The main purpose of program and targeted method of real investments financing is a creation of complex mechanism of their financing for the economic entities which would allow to reveal ways of effective and optimal financing of real investments by attraction of private investment capital and reduction of state investment costs level. The purpose of introduction of the program and targeted method of real investments financing is ensuring direct connection between allocation of budgetary funds in the investment sphere and results of their application.

The main goals of the program and targeted method of real investments financing are as follows:

- identification of strategic and tactical targets of investment development;

- support of transparent investment process in the sphere of financing;

- improvement of investment policy development, efficiency of distribution and application of funds;

- support and providing of a system approach to financing;

- detection of optimal sources of investments financing;

- timely and full control on investment financing.

\subsection{Taxonomic method}

Implementation of program and targeted method starts form revealing and setting of final goals. The goals usually reflect desirable situation which the financing system should reach from a current situation within a certain period of time after solving of a set of problems distinguishing the set situation from the initial one.

The algorithm of the program and targeted method of real investments financing includes four interconnected stages: analytical, resource, expert and control (figure 1).

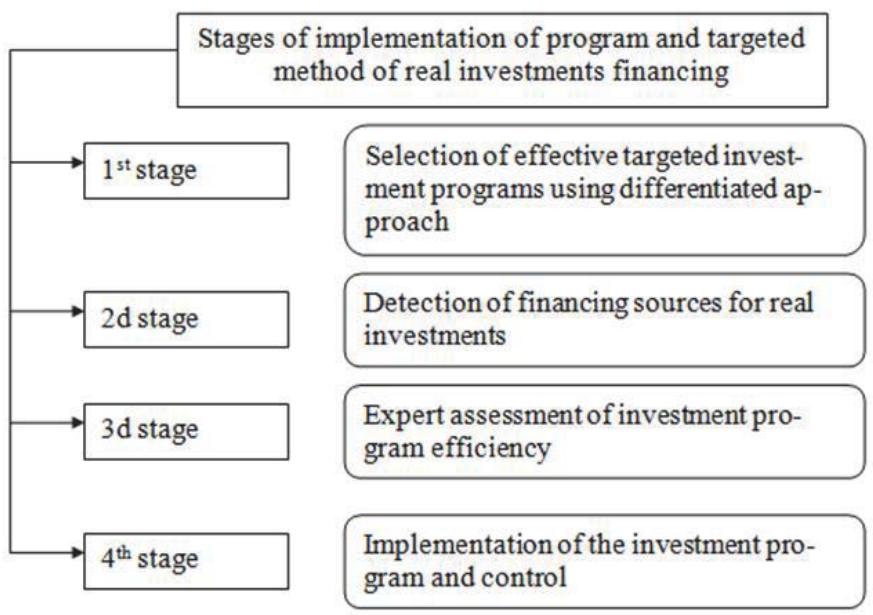

Figure 1. Stages of implementation of program and targeted method of real investments financing

\subsection{Method of observational generalization and logical inference}

Advantages of program and targeted method of real investments financing consist in implementation of the following principles and opportunities:

1) principle of priority of real investments financing, according to goals of investment development of economy with further search and detection of effective ways, actions for their achievement and resource support;

2) financing of investments in dynamical economic environment and integration of the capital caused by intersectorial and inter-regional coordination and high level of differentiation of the investment capital and risk;

3) implementation of strategic targets providing drastic changes in development of investment sphere, infrastructural or other elements of regional economic systems;

4) drastic changes in adverse proportions, structure, trends of economy and investment sphere development;

5) use of effect of the money multiplier at targeted financing of the limited budgetary resources by additional attraction of private investments, own funds of the interested state and commercial enterprises and companies, bank credit, foreign investors.

6) combination of program and targeted method of real investments financing with methods of regional financial planning and forecasting at state financing at all territorial and structural levels. 
Use of the program and targeted method of real investments financing presupposes effective development of concession activity in state and private partnership at financing of real investments. This method allows to accumulate limited financial resources of the state by carrying out of a structural investment policy for accelerated development of processing industry branches, preferred financing of priority real investment projects of economy and social sphere development, development of knowledge-intensive production.

The basic tools of the program and targeted method of real investments financing are target programs and financial and credit mechanism for attraction of real investments.

\section{Results}

As a rule, budgetary financing of real investment projects is carried out by financing as a part of targeted programs and financial support of Investment fund of the Russian Federation. The investment fund of the Russian Federation is created for implementation of the investment projects of national-level importance which are carried out on the terms of state and private partnership. The main directions of the state support by means of this fund are connected with modernisation of non-commercial infrastructure, basic capital and technologies of strategic priorities of the state, as well as with creation and development of the Russian innovative system, support of institutional reforms. The order of formation of the Russian Federation Investment fund, the forms, mechanisms and conditions of granting of the state support using its means are defined by Regulation on Investment fund of the Russian Federation. The financial support of projects which have passed competitive selection presupposes application of such forms as co-financing of the investment project on contractual conditions, with registration of the property rights of the state, allocation of funds to authorized capitals of legal bodies, providing of state guarantees.

In Russia financing of investment projects as a part of targeted programs is connected with implementation of federal investment programs (Federal targeted investment program, federal targeted programs), departmental, regional and municipal target investment programs.

Federal targeted programs are used as tools for program and targeted method of real investments financing, as well as for implementation of priority goals in the sphere of state, economic, social development of the country. They are financed from the federal budget, budgets of federal subjects, municipal entities and off-budget means. Priority sectors which need the state support for implementation of investment projects from the federal budget are defined by the Ministry of economic development and trade and the Ministry of Finance of the Russian Federation in coordination with other federal public authorities. The objects of basically federal importance (buildings and objects of new building and modernization for federal state needs), are included to the Federal targeted investment program (FTIP) which defines amount of the state investments according to branches and departments. The list of the objects financed by FTIP is drawn up according to volumes of the state capital investments directed on implementation of the federal target programs, and on solving of specific social and economic questions not included in these programs on the basis of offers approved by the President of the Russian Federation or the Government of the Russian Federation. Drawing up of this list is carried out by the Ministry of economic development and trade of the Russian Federation taking into account offers of the state customers for investment projects, results of contract tendering and concluded state contracts. Aggregate data on the federal targeted programs provided for financing from the federal budget in 2015 (table 1) are given below, according to the official site of the Ministry of economic development of the Russian Federation.

Table 1 - Federal targeted programs provided for financing from the federal budget in 2015.

\begin{tabular}{|c|c|c|c|c|c|}
\hline \multirow{2}{*}{ № } & \multirow{2}{*}{ Section of the federal targeted programs } & \multirow{2}{*}{$\begin{array}{c}\text { State capital investments, } \\
\text { in } \% \text { from total }\end{array}$} & \multicolumn{2}{|c|}{ Current expenses in \% from total } & \multirow{2}{*}{$\begin{array}{c}\text { Overall amount of } \\
\text { financing, in \% from total }\end{array}$} \\
\hline & & & R\&D & Other needs & \\
\hline 1. & Development of high technologies & \begin{tabular}{|c|}
13,5 \\
\end{tabular} & 98,3 & 16,3 & 28,6 \\
\hline 2. & Accommodation & 2,4 & -- & 13,2 & 4,6 \\
\hline 3. & Transport infrastructure & 42,6 & 0,5 & 41,6 & 35,3 \\
\hline 4. & Russian Far East & 5,7 & -- & -- & 3,3 \\
\hline 5. & Rural development & 2,3 & 0,02 & 2,7 & 2,0 \\
\hline 6. & Social infrastructure & 8,0 & 0,3 & 10,2 & 7,2 \\
\hline 7. & Safety & 6,2 & 0,8 & 11,3 & 6,5 \\
\hline 8. & Development of regions & 18,2 & -- & 2,4 & 11,3 \\
\hline 9. & Development of state institutions & 1,1 & 0,08 & 2,3 & 1,2 \\
\hline & TOTAL & 100,0 & 100,0 & 100,0 & 100,0 \\
\hline
\end{tabular}


The presented statistical data allows to make a conclusion that the main attention is paid to high technologies and transport infrastructure. The dynamics of total financing amount of federal targeted programs for 2011-2015 (figure 2) shows certain stability in financing except of insignificant deviations.

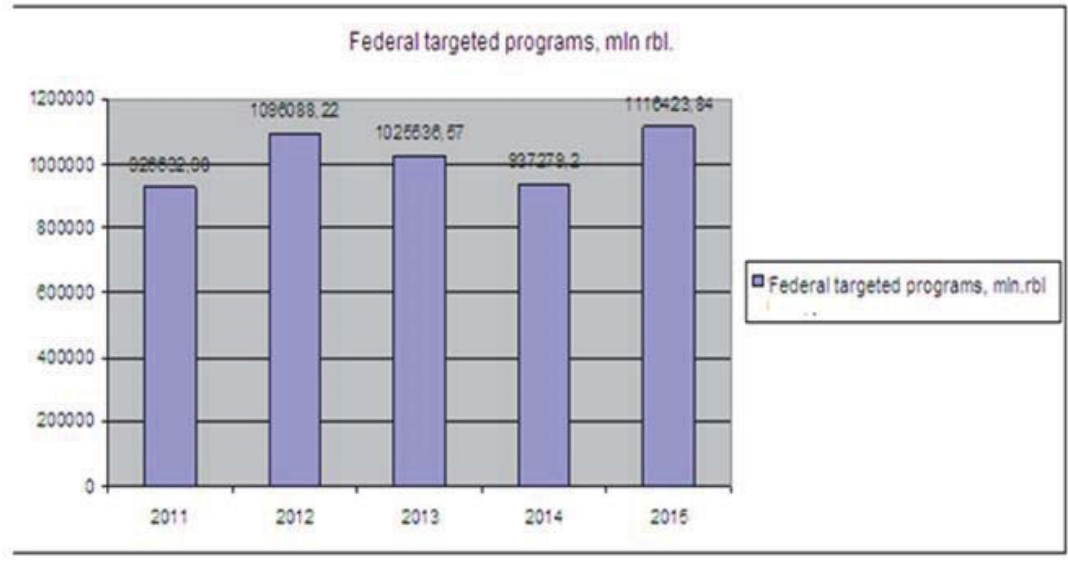

Figure 2. Total amount of financing of federal targeted programs in 2011-2015 from the federal budget.

Investments programs developed by the program and targeted method get certain targeting, i.e. financial liability in real investments financing. At the current stage, participation of the state in real investments financing on the basis of the program and targeted method of investments financing allows to give certain privileges to economic entities and to carry out due control over targeted application of allocated funds.

First of all, the program and targeted method of real investments financing promotes observance of the uniform approach to efficient use of funds for solving of the most urgent problems, and secondly this method is a tool for stabilization of economic situation of certain regions.

During scientific research, the authors are going to provide substantiation of the financial and credit mechanism for attraction of real investments as a tool of the program and targeted method of their financing.

\section{Discussion}

The problem of functioning of the financial and credit mechanism is topical today. This problem was interesting for economists at various stages of national economy development. We are going to examine some theoretical questions connected with functioning of the financial and credit mechanism. The modern science contains different interpretations of the financial and credit mechanism. Various authors consider it in own way, thus implying a set of standard norms and rules, considering it as a set of various forms and methods of application of financial and credit resources.

The concept of financial and credit mechanism is widely used the economic literature. But still there is no common opinion concerning its definition and its components. The literature analysis showed that many economists consider a concept of «financial and credit mechanism» as the financial mechanism. Special attention among a variety of definitions and approaches of scientists and experts to this term can be drawn to two approaches. The first approach consists in treating financial mechanism as functioning of finance of the enterprises. This approach reflects internal arrangement of the enterprises' finance; thus this concept cannot be identified with the financial mechanism. The second approach treats financial mechanism as a set of methods and forms, tools, ways and levers of influence over condition and development of the enterprise. This approach reflects external influence of functioning of the enterprises' finance, characterises the finance as a decisive factor of influence of management over organisation's economic condition. In this case, it is necessary to define its components and structure.

Some researchers consider financial and credit mechanism as a way of arrangement of financial relations which consists of elements and tools of influence over economic processes in a society. It seems to us that such interpretation does not reflect neither problems, nor the purposes, the essence of financial relations arrangement. The substantiation of authors concerns only indirect structuring of the financial and credit mechanism elements.

The other group of economists considers financial and credit mechanism as a precise structuring of certain subsystems including financial and credit planning, financial and credit levers, organizational structures and legal order of financial and credit system. These authors reflect the basic feature of administrating control over economy in details, but 
it is almost impossible to develop a system of financial and credit mechanism on this basis.

Another one group of researchers suppose the financial and credit mechanism includes two subsystems: financial and credit support and financial and credit regulation, as well as organizational structures and influence levers. We consider this approach as the most interesting, though it is not adequate to the present, since it does not define the main participant of economic conversions. It is commonly known that any economic process should have a head whose tasks include defining a direction of economic development. If the head is not defined, there can be different interpretations in strategic and tactical problems of cluster or economic segment development.

The concept of financial and credit mechanism means interconnection and interference of all constituent elements which defined possibility of effective functioning for achievement of set goals. Thus the big attention is drawn to systemacy and complexity approach of finance management. The role of financial and credit mechanism is shown in the diagram of management of investment relations in economic system (figure 3).

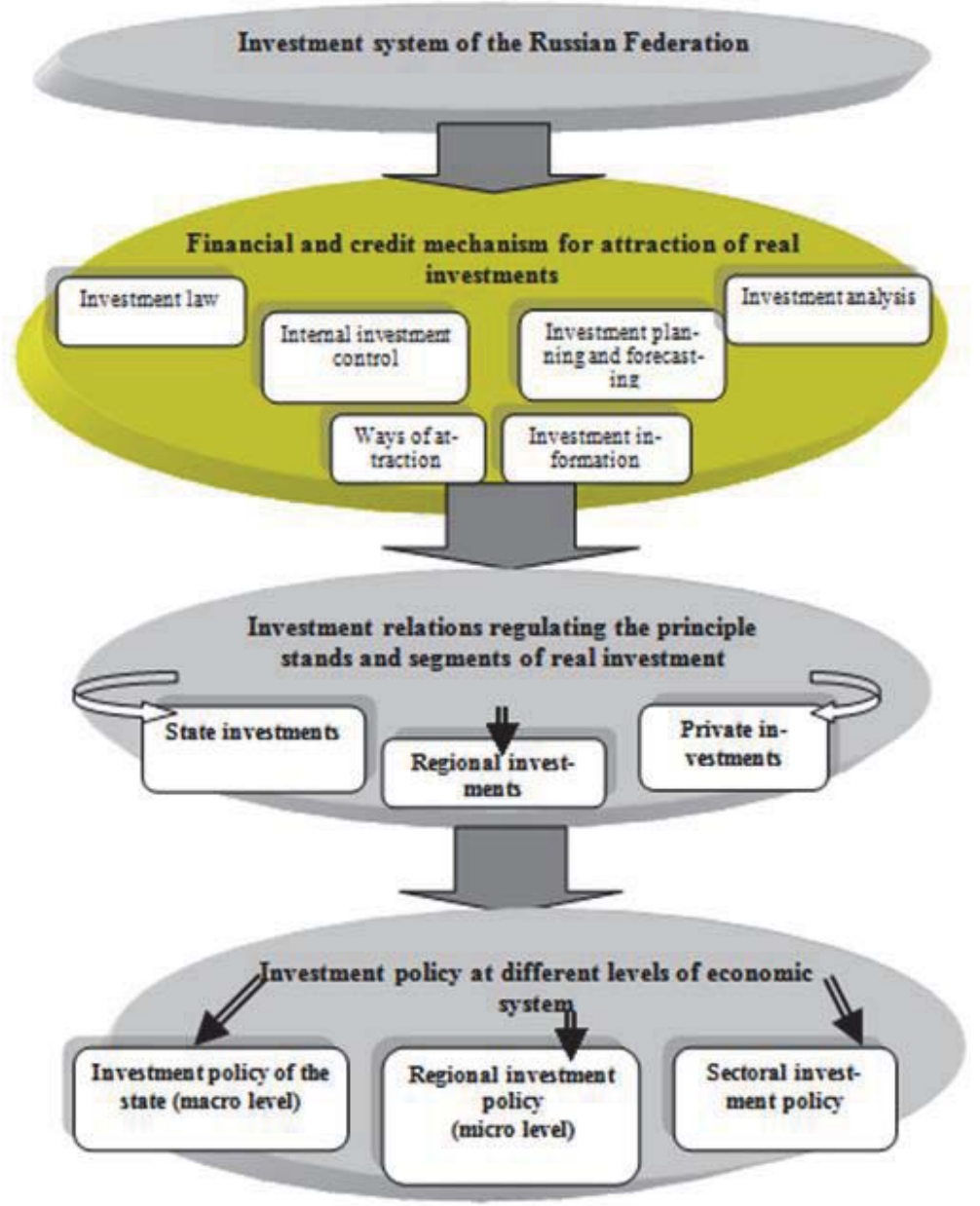

Figure 3. Financial and credit mechanism for attraction of real investments

First of all action of the financial and credit mechanism is directed on detection of additional reserves of development and expansion of production. The financial and credit mechanism includes a complex of subsystems of influence over making of administrative decisions in economic entities activity. The final goal of this influence is support of normal functioning conditions of finance and credit at nation-wide level, i.e. formation of deficit-free budget, financing and crediting of planned actions, control over plan implementation, observance of established order and balance between formation and application of funds.

Theoretical researches of authors allowed to make a conclusion that there is currently no uniform opinion opening the essence of financial and credit mechanism. Existing definitions and structure of the financial and credit mechanism depend directly on understanding of the essence of these economic categories by theorists.

In the research the authors suggest to treat the financial and credit mechanism for attraction of real investments as 
a tool for control over investment relations in the uniform investment system for regulation of money flows. These relations represent a set of various spheres (links) which are interconnected and united by basic unity within the base category of "investment". Thus, each sphere in its turn consists of separate clusters.

The financial and credit mechanism for attraction of real investments is a component of uniform investment system which covers specific sphere of investment relations. The authors suppose that this mechanism provides opportunity of targeted influence of financial and investment establishments on investment relations, and creates necessary prerequisites for redistribution of money flows in various segments of the financial market.

The special attention in scientific research is given to the state investment policy in conjunction with financial and tax policy. The state has essential influence over investment activity in society, thus there is a need to create adequate tools of investment policy for formation of favourable investment climate both at macro and micro levels.

The state investment policy is a component of financial policy which shows position of the state to financing of investment activity. First of all, it determines purposes and directions of investments; secondly - forms of state regulation of investment activity. The national investment policy consists from a set of rules and tools for investments regulation. The investment policy is a component of a macro economic policy and corresponds to its separate directions (currency, tax, monetary, etc.).

Currently significant attention is drawn to questions of investment policy at both macro and micro level. The state investment policy provides creation of real opportunity and conditions for investment, active participation of the state in the investment market promotes its development.

The economic literature uses the following definition of the state investment policy: this is a complex of targeted actions carried out by state and aiming to create favourable conditions for all economic entities in order to promote investment activity, improve economy, increase of production efficiency and perform tasks of social development.

On the basis of documents of Department of the investment policy of the Ministry of economic development of Russia, the investment policy is treated as creation and maintenance of such a supply in the capital market which would cover to the utmost demands of economy for investments of a certain volume and structure which are set on the basis of proprietary interest of economic entities in economic benefit from these investments.

Thus, the investment policy of the state is a set of the actions carried out by the state for control over investment activity in order to create optimal conditions for promotion of the investment process.

The main goal of investment policy of the state is creation of favourable investment climate for improvement of investment process. It is necessary to observe the following organization principles (figure 4) while developing and implementing the state investment policy.

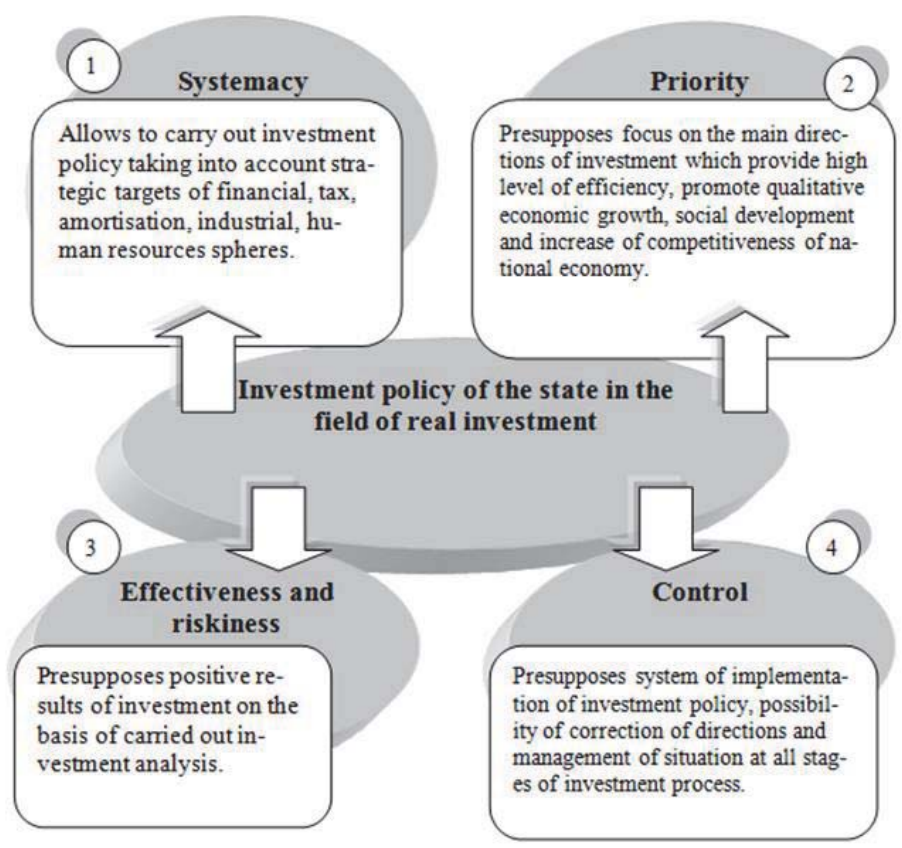

Figure 4. Principles of development and implementation of the state investment policy in the sphere of real investment 
The key goals of the state investment policy are as follows:

1. Support (promotion) of certain branches of economy.

2. Support of balanced development of branches of economy and export production.

3. Creation of a competitive domestic production.

4. Implementation of social and ecological programs (development of public health services, education, housing and communal services, environmental protection).

5. Regulation of the population employment.

6. Support of defence capacity and safety of the state.

The mechanism which provides observance of the investment policy (figure 5) is necessary for its implementation. The state investment regulation is directed on support of the maximum efficiency of investments. In the conditions of market relations there are direct and indirect methods of state investments regulation, as well as administrative and economic means for this regulation. Both methods and means are directed on solving the common goals and objectives.

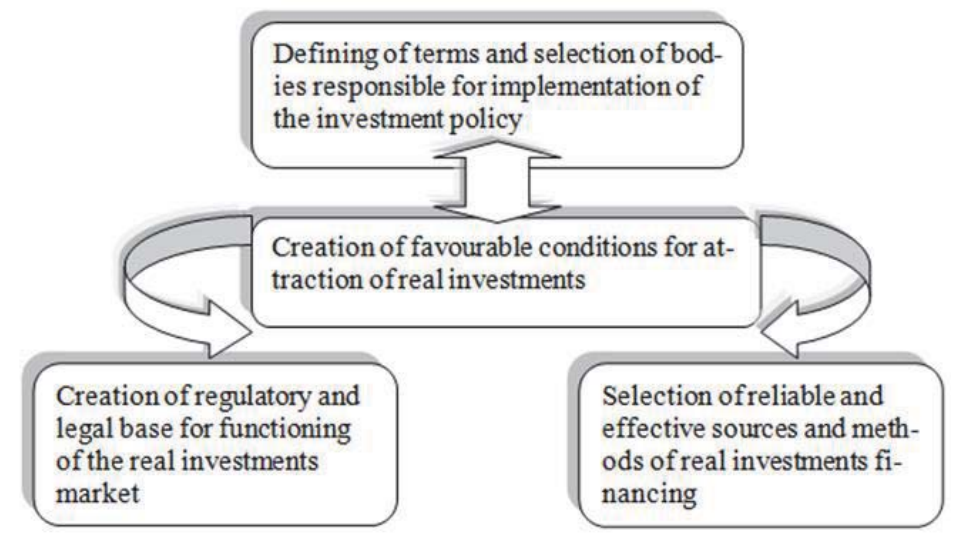

Figure 5. Mechanism of the investment policy implementation

Active influence of the state on investment processes is a prerequisite for support of favourable investment climate and promotion of investment activity which allows to ensure stable development of social and economic system as a whole to public ends.

Both administrative and economic means of influence on investment processes are used at direct methods of state regulation of investment activity. When applying administrative means, the state influences investment processes directly, based on resolutions of mandatory type which are subject to compulsory implementation. These means can include state registration of economic entities, licensing, establishment of quotas for export and import, management of the state enterprises and state properties, administrative procedures, etc. Direct economic influence consists in investment in certain territories, branches, enterprises which cannot sustain a severe competition of the market due to their specific. For example, in the high technology branches of economy the risk of investments is high, investment process proceeds with pauses, thus projects are considered as long-term and expensive.

Let's examine some types of direct state regulation of investment activity in more details.

The state investments are directed on solving of strategic problems of the state policy, and usually do not have a commercial character, therefore sometimes they are considered to have low economic efficiency. Efficiency of the state investments should be considered on a national scale, because of their orientation on stable economic growth and social progress of a society. Russia should create the mechanism for support of efficiency of the state investments application. The main directions of creation such mechanism were already stated. They include: increase of the program and targeted component of the state regulation; development of project instruments for cooperation between the state and business on the basis of joint financing of projects connected with support of infrastructure and promotion of competitive positions of corporate sector of economy; providing of capital transfers on a share basis for purposes of social and economic development of regions.

Indirect methods of the state regulation presuppose only economic levers on investment processes. These levers include tools of budgetary, tax, monetary and credit policy. They influence economic entities mediately promoting them to certain actions directed for solving of the state investment policy problems.

It is necessary to note legal means of regulation of the investment activity which are implemented using a system 
of regulations and rules of the civil and economic legislation, since creation of legal base is a function of the state only. The main tools of this category include conclusion of investment contracts and credit relations, development and approval of government programs, making of laws and by-laws, system of their implementation. Legal means provide implementation of administrative and economic means of the state influence.

The first federal targeted programs were established in 1993, and their number increased every year. This resulted in situation when the volume of necessary investments has considerably exceeded resources of the state for their implementation. Financing made only a scanty share from the stated volume of investments in some programs. Currently the system of the state investment policy is directed on determination of priority directions of investments application which would ensure no dissipation of public funds.

The special attention is now drawn to national projects. They are carried out according to priorities of the country development, under the president's control, within shorter terms than the terms required for implementation of the federal targeted programs. Besides, the principle of project financing using specially created structure, on the basis of end-to-end planning, reporting and control is considered in projects with expenses of at least 5 billion rbl.

When determining reference criteria of national projects it is necessary to consider orientation of a project on structural reforms, increase of national economy and improvement of the quality of life of the RF citizens. Concentration of the state investments on the main directions of industrial development, selection of investment projects are conditions of achievement of goals and purposes of the state investment policy which have no alternative, in the conditions of limited investment resources. Human investments become the main direction of the state investments policy at the current stage. The state has stated the following priorities: education, public health services, providing of affordable housing and agriculture.

Large investments which are parts of national projects should be directed on development of potential advantages of the Russian economy, on creation of new products which have no analogues in the world market, on increase of competitiveness of existing enterprises, on support of decent working and living conditions of the population.

The branch orientation of investment activity is very important for setting priorities in the state investment policy. Considering investment process as integral part of social reproduction, it is necessary to direct investments flows to progressive branches of economy which produce products competitive in both domestic and international markets. Therefore, the investment policy at level of certain branches and intersectorial complexes is a component of the state investment policy. Stages of implementation of a branch investment policy are shown in figure 6 .

The branch investment policy is an activity directed on investment support of priority sectors of economy which development would provide economic and defensive safety of the country, export of industrial production, promotion of scientific and technical progress and dynamical development in the long term.

Being a part of the state investment policy, the branch investment policy should provide determination of strategic targets and directions of investment activity in sectors, rational structure and efficient application of investments and sources of their covering, modernization of structure of the basic production assets, thus creating conditions for development of competitive production and steady economic growth.

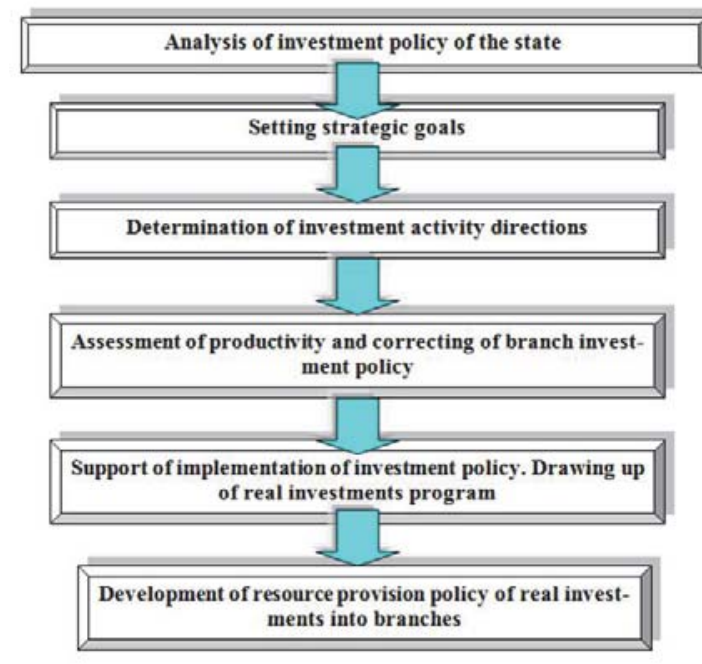

Figure 6. Stages of the branch investment policy 
The financial and credit mechanism for attraction of investments provides workable management of investment relations, i.e. influence of the subject on the object of investment system using external form of investments practical functional which includes modern tolls for management of real investments.

Methodological approach based on structuring of investments allows to offer a modular type of the financial and credit mechanism for investments attraction which includes segments of real investment and investment policy at different levels of national economic system. Modularity allows ranging of principles of development and implementation of the state investment policy in the field of real investment.

When implementing direct financial regulation process by carrying out of the corresponding fiscal (budgetary and tax) policy, the state can promote or limit investment processes in a society using certain tools. Influence of the state in the name of the Central bank and the Government of the Russian Federation on activity of money and credit system for in order to regulate business activity in economy was determined in the general context of research.

Prerequisite for support of a favourable investment climate and promotion of investment activity is an active influence of the state on investment processes which allows to provide the maximum efficiency of investments and stable development of social and economic system as a whole.

Functioning of the financial and credit mechanism for attraction of investments is conditional on organizational, economic and legal bases in investment sphere. Practical implementation of each component of the financial and credit mechanism for attraction of investments presupposes action of the corresponding financial tools and turnover of necessary amount of funds. Multistage investment relations within the real investment aiming to conform to the fundamentals of the market economy are now created in the Russian Federation.

The authors suppose that efficiency of the state investment policy depends not only on total amount of real investments, but also from the branches where investment flows will be directed to. Thus, the investment policy of the state in the field of real investment should provide a system approach to management of investment activity and create optimal conditions for promotion of the investment process.

In many respects investment activity depends on the developed investment climate in the country, political and social situation. The system of investments financing should provide a steady growth of national economy under condition of creation a favourable investment climate and effective functioning of financial and credit mechanism for investments attraction.

\section{Conclusion}

Role participation of the state in a system of real investments financing holds a special place in investment sphere. It is necessary to note that sharp increase in volume of the state investments proves that in the conditions of financial crisis, the Government of the Russian Federation has taken profound measures to rescue the real sector, but with the help of the bank system.

Writing team of scientific research considers that in the conditions of dynamical economic environment, the program and targeted method, along with financial planning and forecasting methods, serves as a key tool for implementation of the state investment policy of country and its regions development. Use of the program and targeted method presupposes adequate improvement of system of real investments financing both at federal and regional levels.

Efficiency of the program and targeted method is a result of its system integrating character. It unites functional advantages of methods of search for optimal investment solutions, flexible setting of purposes according to requirements and possibilities of the economic environment. In this case, financing of real investments is carried out, and the infrastructure of the investment project is improving.

The article presents analysis of a wide range of theoretical and practical questions and problems of investment activity. The carried out research allowed to make a number of theoretical and practical propositions and conclusions on debatable directions of functioning of the financial and credit mechanism as a tool for attraction of real investments in funds flows regulation system.

\section{Acknowledgments}

The writing team would like to express gratitude to Tsentrer Yan Vladimirovich, the manager of the Ekaterinburg branch of JSC "Gazprombank", Hachin Aleksander Nikolaevich, manager of JSC "Sberbank Rossii" of the Southern branch for providing a representative samples of analytical data on functioning of the financial and credit mechanism for attraction of real investments in funds flows regulation system in a context of scientific research. 


\section{References}

Alekseev, V. N., Ilyin V.V (2012). Investment climate and international financial center in Moscow: trends and prospects. Publishing house: INFRA-M. 126p.

Askinadzi, V.M. (2012). Investment business. Study guide. Publishing house: UK: IDO PRESS. 764p.

Baldin, K.V. (2012). Investments: system analysis and management. Publishing house: ITK Dashkov and Co. 288p.

Baldin, K.V., Perederyaev I.I., Golov R.S. (2012). Investments in innovation. Publishing house: ITK Dashkov and Co. 238p.

Ivleva, N.V., Komarevtseva O. O. (2014). Forecasting of investments into economy of Russia by application of method and vindications of statistical analysis//Finance and credit, № 36(612). pp.29-37.

Kadyrova, G.M. (2012). Finance investment potential of the Russian Federation: international aspects of formation and application. LLC Ankil. 232p.

Kalyadina, T.V. (2013). About carrying out of IPO on example of companies which have placed stocks at a stock exchange RTS.- M.: Publishing house LIBROKOM. 247p.

Kapralova, E.V. (2013). Policy of liberalization and promotion of investments as a factor of incentives of inflow of foreign capital in the Russian economy//Finance and credit, № 40(568). pp.71-76.

Lomtatidze, O. A. (2012). Regulation of activity in the financial market. Publishing house KnoRus. 288p.

Mishin, Yu.V. (2012). Investments. Publishing house: KnoRus. 288p.

Murphy, John (2012). International analysis: principles of interaction of financial markets. Publishing house: Alpina Publisher. 299 p.

Orlova, S.S. (2012). Investments. Publishing house: Omega-L. 240 p.

Topical problems of financial markets and financial institutions. Les problems actuels des marches financiers et les instituts des finances: collection of research papers/ under editorship of E.G.Knjazeva, L.I.Yuzvovich. - Ekaterinburg: Publishing house AMB, 2013.$322 p$.

Shiryaev, V. I. (2013). Financial markets: neural nets, chaos and non-linear dynamics.- M.: Publishing house LIBROKOM. 232p.

Srebnik B.V. (2012). Financial markets: professional activity in securities market. Publishing house: INFRA-M. 366 p.

Suetin, A.A. (2011). Financial economy: expansion, stability, recession. Publishing house: Alpha-M, 2011.

Vorotilova, N.N., Katkova N.A., Maltseva Yu.N. (2012). Management of investments. ITK Dashkov and Co. 2012. 188p.

Yanova, P. G., Kapralova E.V. (2014). Analys of criteria of investment prospects of the Russian economy//Finance and credit, № 22 (598). pp.59-66.

Yusvovich, L.I. (2012). Concept and methodology of real investments attraction: (monography). Ekaterinburg: Publishing house of Ural University. 316p.

Yusvovich, L.I., Pyatin A.N., Istomina Yu.V., Yudinf E.A. (2014). Features of real investment in conditions of capital integration: international and Russian aspects: monography/ L.I. Yusvovich, A.N. Pyatin, Yu.V. Istomina, E.A.Yudina. M: Publishing house of Academy of Natural sciences. 302 p.

Zubchenko, A.I. (2012). Foreign investments. Publishing house: Knigodel. 184p. 
ISSN 2039-2117 (online) ISSN 2039-9340 (print)
Mediterranean Journal of Social Sciences MCSER Publishing, Rome-Italy
Vol 6 No $3 \mathrm{~S} 3$ May 2015 